\begin{tabular}{lll}
\hline Jurnal Pendidikan Dasar Perkhasa & \\
& & P-ISSN 2461-078X \\
E-ISSN 2654-783X
\end{tabular}

\title{
UPAYA MENINGKATKAN HASIL BELAJAR MATEMATIKA SISWA KELAS 4SD MELALUI MODELPEMBELAJARAN KOOPERATIF TIPE TEAMS GAMES TOURNAMENT BERBANTUAN MEDIA PAPAN BERAT
}

\author{
Muhammad Anwar Romdhoni ${ }^{* 1}$, Bambang Suteng Sulasmono ${ }^{2}$, Eunice Widyanti \\ Setyaningtyas ${ }^{3}$ \\ 1,2,3Program Studi PGSD, Universitas Kristen Satya Wacana \\ Diterima: 21 Maret 2019. Dipublikasi: 5 April 2019.
}

\begin{abstract}
The aim of the study was to improve student learning outcomes on Mathematics subjects through the application of Teams Games Tournament assisted by heavy board media. This type of research uses Classroom Action Research (CAR). The research subjects were the fourth grade students of Ujung-Ujung SDN 03 totaling 18 students. Data collection tools using observation sheets, test questions are then analyzed with quantitative descriptive data. The results showed an increase in the percentage of learning outcomes of students who reached KKM in the pre-cycle, showing that from 18 there were 4 with values reaching KKM (37\%) increasing in the first cycle to 14 students completing with a percentage of $78 \%$ and increasing again in cycle II reaching $100 \%$. This increase occurs because students begin to understand the concept of Mathematics. The results of the study can be concluded that the application of the Teams Games Tournament learning model assisted by heavy board media can improve the mathematics learning outcomes of 4 th grade students in elementary school.
\end{abstract}

Keyword: Learning Outcomes, Mathematics, Teams Games Tournament, Heavy Board Media.

Abstrak. Tujuan penelitian untuk meningkatkan hasil belajar siswa pada mata pelajaran Matematika melalui penerapan pembelajaran Teams Games Tournament berbantuan media papan berat. Jenis penelitian menggunakan Penelitian Tindakan Kelas (PTK). Subjek penelitian adalah siswa kelas IV SDN Ujung-Ujung 03 berjumlah 18 siswa. Alat pengumpulan data menggunakan lembar observasi, soal-soal tes kemudian dianalisis dengan data deskriptif kuantitatif. Hasil penelitian menunjukkan peningkatan persentase hasil belajar siswa yang mencapai KKM pada pra siklus, menunjukan dari 18 terdapat 4 dengan nilai mencapai KKM (37\%)meningkat pada siklus I menadi 14 siswa tuntas dengan presentase $78 \%$ dan meningkat lagi pada siklus II mencapai $100 \%$. Peningkatan ini terjadi karena siswa mulai memahami konsep Matematika. Hasil penelitian dapat disimpulkan bahwa penerapan model pembelajaran Teams Games Tournamentberbantuan media papan berat dapat meningkatkan hasil belajar matematika siswa kelas 4 sekolah dasar.

Kata Kunci: Hasil Belajar, Matematika, Teams Games Tournament, Media Papan Berat. 


\section{Pendahuluan}

Pembelajaran merupakan kegiatan belajar yang dilaksanakan siswa melalui usaha yang terencana dengan memanipulasi sumber-sumber belajar sehingga terjadilah proses belajar (Mawardi, 2018:27). Pada kurikulum 2013 proses belajar terjadi bukan berpusat pada guru, akan tetapi pembelajaran yang berpusat pada siswa. Oleh karenanya guru harus mampu memfasilitasi siswa untuk membangun pengetahuan sendiri dan memperoleh keterampilanketerampilan yang bisa membuatnya memecahkan masalah, terutama pemecahan masalah matematika. Matematika adalah ilmu yang mempelajari tentang bilangan, bentuk-bentuk (geometri) yang dihitung melalui simbol-simbol, yang memerlukan kemampuan berfikir khususnya berlogika dan berfikir rasional, (Wahyudi \& Siswanti, 2015: 26). Menurut Normala \& Anugraheni (2017: 243) “Matematika merupakan salah satu disiplin ilmu yang meningkatkan kemampuan berfikir dan berargumentasi dan memberikan konstribusi ilmu dalam menyelesaikan masalah sehari-hari maupun saat masuk dunia keria, maka dari itu *surel korespondensi: 292015058@student.uksw.edu matematika sangat penting untuk siajarkan sedari dini". Berdasarkan pendapat tersebut dapat diartikan bahwa matematika adalah sebuah disiplin ilmu untuk meningkatkan kemampuan berfikir kritis dan beralar yang mempelajari tentang bentukbentuk, besaran, susunan yang bermanfaat untuk kehidupan sehari hari terutama untuk penyelesaian masalah yang berhubungan dengan matematika.

Menurut Yustinus (2017: 5-6) mata pelajaran matematika bertujuan agar: (1) memahami konsep matematika, menjelaskan konsep dan mengaplikasikan konsep secara benar dalam pemecahan masalah matematika, (2) memahami pola dan sifat, menyusun bukti, manipulasi matematika, penyampaian gagasan, (3) memecahkan masalah, meliputi kemampuan memahami masalah, merancang model matematika, menyelesaikan model dan menafsirkan solusi, mengomunikasikan gagasan dengan, simbol tabel, diagram atau media lain untuk memperjelas masalah dan (5) memiliki sikap menghargai matematika. Tentunya tujuan dapat tercapai apabila setiap unsur yang 
berkaitan dengan pembelajaran matematika di sekolah memahami standar isi (SI) mata pelajaran matematika.

Pembelajaran matematika SD/MI memiliki objek kajian yang abstrak, bersifat bertahap, dan berpola pikir konsisten. Maka dari itu pembelajaran matematika di SD harus disesuaikan dengan tingkat operasi berpikir anak. Menurut Piaget, usia anak SD masih dalam tahap berpikir konkret (Ibda, 2015: 34). Pada tahap ini siswa sekolah akan lebih memahami materi dengan menggunakan bantuan media-media konkret. Media adalah merupakan segala sesuatu yang digunakan sebagai sarana untuk menyalurkan pesan atau informasi berupa materi pembelajaran sehingga terjadi proses belajar (Mawardi, 2018: 29). Maka dari itu penggunaan media pembelajaran sangat berperan dalam keberhasilan proses belajar. Karena media pembelajaran dapat mempermudah guru dan siswa dalam memahami suatu konsep pembelajaran, serta siswa akan lebih tertarik mengikuti pembelajaran karena siswa terlibat langsung dalam pembelajaran.
Mulyani (2016:

"Pembelajaran matematika di sekolah dasar tidak mudah untuk dilaksanakan karena karakteristik siswa dan karakteristik matematika di sekolah dasar". Pembelajaran matematika yang dilaksanakan di sekolah dasar memiliki karakteristik tersendiri, baik dari segi matematika dan karakteristik siswa. Karakteristik matematika di sekolah dasar yaitu pembelajaran yang bersifat abstrak sedangkan karakteristik siswa di usia sekolah dasar mudah memahami pembelajaran dengan benda-benda konkret. Maka dari itu, pembelajaran harus dilaksanakan sesuai dengan tingkat perkembangan siswa usia sekolah dasar dan dibantu dengan menggunakan media pembelajaran yang mempermudah pemahaman peserta didik dengan konsep matematika.

Berdasarkan hasil pengamatan dan di SDN Ujung-Ujung 03 ditemukan masih jauh dari kondisi ideal. Hal ini disebabkan pemahaman konsepkonsep dasar pada mata pelajaran matematika masih sangat rendah. Selain itu banyak siswa minat belajarnya sangat rendah sehingga hal ini juga berdampak pada hasil belajar 
siswa yang masih dibawah kriteria ketuntasan minimal (KKM) yang ditetapkan oleh sekolah. Berdasarkan hasil pengamatan pada nilai ulangan kelas 4 pada mata pelajaran matematika masih banyak siswa yang hasil belajarnya belum mencapai KKM. Penyebab rendahnya rendahnya hasil belajar siswa adalah pembelajaran masih menggunakan pembelajaran ceramah dan kurang menggunakan media pembelajaran yang konkret. Guru hanya menggunakan media yang tersedia di kelas seperti Lembar Kerja Siswa (LKS), dan membuat siswa kurang antusias untuk terlibat dalam kegiatan pembelajaran sehingga hasil yang dicapai siswa kurang optimal.

Salah satu alternatif pemecahan masalah yang dapat digunakan untuk memecahkan masalah tersebut adalah dengan menggunakan model pembelajaran kooperatif tipe Teams Games Tournament berbantuan media papan berat. Model pembelajaran Teams Games Tournament (TGT) adalah salah satu tipe atau model kooperatif yang mudah diterapkan, melibatkan aktivitas seluruh siswa untuk memecahkan masalah matematika yang dilaksanakan secara kelompok, menumbuhkan tanggung jawab, kejujuran, kerjasama persaingan sehat dan keterlibatanbelajar. Menurut Nasution (2018: 145-146) "Model pembelajaran Teams Games Tournament (TGT) merupakan pembelajaran berbasis kelompok yang dapat meningkatkan pola interaksi guru dan siswa". Artinya dalam model Teams Games Tournament (TGT) interaksi antara siswa dan guru maupun sebaliknya dapat menciptakan suasana baru di dalam kelas dengan diskusi kelompok, bertanya jawab, maupun menyampaiakan informasi kepada teman yang lain dan berjalan dengan efektif dan efisien.

Menurut Fathurrohman (2015: 56) model Pembelajaran Teams Games Tournament (TGT) dibagi menjadi lima atara lain: 1) Tahap penyajian kelas (class precentation). 2) Belajar dalam kelompok (teams). 3) Games. 4) Tournament, dan 5) Penghargaan Kelompok (Rekognisi Tim). Dari lima langkah pembelajaran matematika dengan menggunakan model pembelajaran Teams Games Tournament (TGT) kemudian disusun menjadi langkah langkah pembelajaran sesuai dengan media pembelajaran papan berat. Dengan 
demikian

langkah-langkah

pembelajaran diharapkan dapat

meningkatkan hasil belajar siswa.

Berikut ini langkah langkah pembelajaran dengan model Teams

Games Tournament (TGT) disertai dengan media papan berat 1) Penyajian kelas (class presentation). Guru menyampaikan materi kepada siswa dengan bantuan media papan berat. Media papan berat digunakan untuk menjelaskan materi tentang pengukuran berat. Di dalam media papan berat bukan hanya menampilkan materi teetapi juga menampilkan evaluasi yang digunakan untuk games 2) Teams. Guru membagi siswa dalam kelompok secara heterogen. 3) Game. Guru menyediakan kertas bernomor yang berisikan pertanyaan yang sesuai dengan materi. 4) Tournament. Setiap kelompok memilih wakilnya untuk mengikuti turnament. Siswa yang terlebih dahulu menjawab pertanyaan akan mendapat skor. Siswa yang terlebih dahulu menjawab makan akan menemelkan kertas di papan berat. Dan 5) Guru memberikan penghargaan kepada kelompok yang mendapatkan skor tertinggi.

\section{Metode}

Jenis penelitian ini merupakan Penelitian Tindakan Kelas (PTK). Subyek penelitian ini adalah siswakelas IV SDN Ujung-Ujung 03, dengan jumlah siswa 18. Rancangan penelitian yang digunakan dalam penelitian ini adalah model spiral yang dikemukakan oleh Kemmis \& MC Taggart dimana setiap siklus terdiri dari 4 tahap yaitu perencanaan, pelaksanaan, observasi, serta refleksi (Saputra, 2016: 3). Teknik pengumpulan data dalam penelitian meliputi tes, observasi dan dokumentasi. Tes berupa tes objektif yang terdiri dari 20 soal yang diberikan diakhir setiap siklusnya. Sedangkan observasi pada penelitian ini dilakukan untuk mengamati tindakan guru dalam menerapkan model pembelajaran Teams Games Tournament (TGT).

\section{Hasil dan Pembahasan}

Pada bagian ini, akan dipaparkan hasil analisis dan data penelitian tentang hasil belajar Matematika pada siswa kelas IV di SDN Ujung-Ujung 03 dengan menggunakan model Teams Games Tournament (TGT) berbantuan media papan berat. Hasil Belajar 
Matematika siswa dari pra siklus, pada tabel 1.

siklus I, dan siklus II dapat dilihat

Tabel 1. Hasil Belajar Matematika kelas IV SDN Ujung-Ujung 03

\begin{tabular}{cccccccc}
\hline Kategori & KKM & \multicolumn{2}{c}{$\begin{array}{c}\text { Kondisi } \\
\text { Awal }\end{array}$} & \multicolumn{2}{c}{ Siklus I } & \multicolumn{2}{c}{ Siklus II } \\
\hline & & $\mathrm{F}$ & $\%$ & $\mathrm{~F}$ & $\%$ & $\mathrm{~F}$ & $\%$ \\
\hline Tuntas & $\geq 70$ & 6 & $33 \%$ & 14 & $78 \%$ & 18 & $100 \%$ \\
$\begin{array}{c}\text { Tidak } \\
\text { Tuntas }\end{array}$ & 12 & $67 \%$ & 4 & $22 \%$ & - & \\
\hline Total & 18 & $100 \%$ & 18 & $100 \%$ & 18 & $100 \%$ \\
\hline Rata-Rata & 63,66 & & 72,22 & & 85,33 \\
\hline
\end{tabular}

Berdasarkan Tabel 1 dapat dilihat bahwa perbandingan nilai hasil belajar kondisi awal, siklus I dan siklus II mengalami peningkatan. Rata-rata hasil belajar pada kondisi awal yaitu 63,66 meningkat pada siklus I menjadi 72,22, mengalami peningkatan lagi pada siklus II menjadi 85,33. KKM Matematika di SDN Ujung-ujung 03 adalah 70. Nilai tuntas siswa adalah 70, apabila nilai dibawah 70 artinya siswa belum tuntas. Pada kondisi awal nilai siswa yang tuntas ada 6 siswa dengan persentase 33\% dan siswa yang belum tuntas sebanyak 12 siswa dengan persentase $\quad 67 \%$. Mengalami peningkatan pada siklus I, siswa yang tuntas ada 14 siswa dengan presentase $78 \%$ dan yang belum tuntas 4 siswa dengan presentase 22\%. Mengalami peningkatan lagi pada siklus II, siswa yang tuntas sebanyak 18 siswa dengan presentase $100 \%$ atau semua siswa dinyatakan tuntas. Sedangkan peningkatan aktivitas guru dan siswa dapat dilihat pada tabel 2 .

\section{Tabel 2. Peningkatan aktivitas Guru dan Siswa}

\begin{tabular}{ccc}
\hline Tindakan & Siklus I & Siklus II \\
\hline Aktivitas Guru & $87 \%$ & $100 \%$ \\
\hline Aktivitas Siswa & $82 \%$ & $100 \%$ \\
\hline
\end{tabular}


Berdasarkan tabel 2 dapat dilihat bahwa aktivitas guru dan aktivitas siswa mengalami peningkatan dari siklus I ke siklus II. Pada aktivitas guru siklus I mendapatkan skor 27 dengan presentase $82 \%$ pada siklus II mengalami peningkatan skor menjadi 31 dengan presentase $100 \%$. Aktivitas siswa juga mengalami peningkatan pada siklus I mendapat skor 16 dengan presentase $82 \%$ mengalami peningkatan pada siklus II mendapat skor 19 dengan presentase 100\%.

Berdasarkan observasi dan hasil belajar yang diperoleh sebelum pelaksanaan tindakan (pra siklus) dapat diketahui bahwa hasil belajar aspek kognitif hal ini disebabkan karena siswa cepat merasa bosan dengan pembelajaran dengan metode ceramah, dan guru hanya menggunkan media yang tersedia seperti Lembar Kerja Siswa (LKS). Proses pembelajaran sebelum dilakukkan tindakan menunjukkan siswa masih pasif saat mengikuti pembelajaran dan cenderung guru yang menjelaskan dan siswa mendengarkan penjelasan dari guru sehingga siswa lebih cepat bosan.Maka dari itu perlu diadakan tindakan untuk memperbaiki hasil belajar siswa.

Penelitian tindakan kelas ini menekankan pada usaha perbaikan untuk dapat meningkatkan hasil belajar Matematika pada siswa kelas 4 SDN Ujung-Ujung 03 dengan menggunakan model pembelajaran Teams Games Tournament. Model Teams Games Tournament menuntut siswa untuk membangun pengetahuan sendiri dengan memecahkan masalah yang siswa hadapi. Dalam pembelajaran siswa akan menerima sedikit materi dari guru kemudian siswa secara berkelompok bersamasama untuk mencari jalan keluar dalam masalah. Siswa secara berkelompok akan melakukan games Setelah siswa mampu memecahkan masalah siswa siswa melakukan Tournament dengan kelompok lain. Kelompok yang mendapatkan skor tertinggi akan mendapatkan penghargaan dari siswa. Guru menjadi fasilitator jadi siswa yang mendominasi pembelajaran bukan pembelajaran berpusat pada guru. Pada akhir pembelajaran guru memberikan evaluasi untuk mengetahui sejauhmana siswa dapat memahami tentang materi dipelajari. 
M.A. Romdhoni, B.S. Sulasmono, E.W. Setyaningtyas | JPDP 5 (1) April 2019, 38-49

Hasil belajar pada pra siklus, yang diajukan melalui games dan menunjukan dari 18 siswa 12 diantaranya memiliki nilai kurang dari KKM (70) atau memiliki presentase $67 \%$, sedangkan siswa yang tunas terdapat 4 siswa dengan presentase $37 \%$ dengan rata rata nilai siswa 63,66. Oleh karena itu dilakukkan pembelajaran dengan model Teams Games Tournament dan dengan menerapkan model pembelajaran Teams Games Tournament dapat meningkatkan hasil belajar siswa. Hal ini terlihat dari peningkatan rata-rata hasil belajar siswa dari pra siklus ke siklus I menjadi 78,22. Pada siklus I siswa yang tuntas sebanyak 14 siswa dengan presentase 78\% sedangkan siswa yang belum tuntas ada 4 siswa dengan presentase 22\%. Hasil observasi guru pada siklus I mencapai 87\% dan hasil observasi siswa pada sklus I mencapai 82\%.

Peningkatan dari pra siklus ke siklus I terjadi karena peserta didik memahami konsep tentang pengukuran panjang dan berat melalui kerja dalam kelompok, games dan tournament. Melalui penerapan pembelajaran Teams Games Tournament siswa lebih aktif serta dapat menyelesaikan permasalaahn tournament. Oleh karena itu hasil belajar siswa meningkat. Akan tetapi peningkatan yang terjadi pada siklus I belum memenuhi target indikator kinerja yang telah ditetapkan yaitu 80\% dari 18 siswa, maka dilanjutkan pada siklus II. Permasalahan yang terjadi pada saat pelaksanaan siklus I adalah (1) guru kurang memberi waktu lebih saat siswa melakukakn diskusi, sehingga siswa tergesa-gesa saat menyelesaikan permasalahan (2) pengkondisian siswa saat pelaksanaan model pembeajaran Teams Games Tournament masih kurang, sehingga ada sebagian siswa yang berbicara dengan teman sebangku dan mengganggu teman yang lain.

Perbaikan yang telah dilaksanakan pada siklus I sesuai dengan rencana berdasarkan refleksi yang dilakukan didapatkan hasil yang lebih baik. Hasil belajar siswa yang mendapatkan nilai lebih dari KKM (70) sebanyak 18 siswa dengan presentase 100\%. Bukan hanya itu hasil observasi guru dan siswa juga mengalami peningkatan sebesar 100\%. Peningkatan hasil belajar dapat terjadi karena dengan menggunakan Teams Games Tournament siswa lebih 
mudah memahami pembelajaran, meningkatkan aktivitas siswa karena siswa sendiri yang membangun pengetahuannya dan lebih mudah dimengerti karena mengaplikasikan pengetahuan yang mereka miliki dengan dunia nyata. Sejalan dengan pendapat dari Shoimin (2014:207)Teams Games Tournament memiliki kelebihan diantaranya 1) pembelajaran akan berpusat pada siswa yang mengakibatkan siswa aktif dalam proses belajar mengajar.2) Menumbuhkan saling menghargai antar siswa. 3) siswa menjadi lebih bersemangat dalam mengikuti pelajaran. Karena dalam pembelajaran ini, guru menyajikan sebuah penghargaan pada siswa atau kelompok terbaik.

Hasil penelitian yang sejalan dengan penelitian Wulansari (2016) dengan judul "Peningkatan Hasil Belajar Matematika dengan Model Pembelajaran Kooperatif Teams Games Tournament". Hasil penelitian menyatakan bahwa penerapan model pembelajaran Teams Games Tournament (TGT) dapat meningkatkan hasil belajar matematika. Hal ini ditujukan dengan peningkatan hasil belajar dari pra sikus sebesar $30 \%$ meningkat pada siklus I menjadi 75\%n dan meningkat pada siklus II yang menjadi 100\%siswa tuntas. Penelitian ini didukung penelitian dari dan penelian yang dilakukan oleh Rahayu,dkk (2017) dengan judul "Peningkatan Aktivitas dan Hasil Belajar Siswa Melalui Pembelajaran Teams Games Tournament ". Hasil penelitian menyatakan penelitian dengan model pembelajaran Teams Games Tournament (TGT) dapat meningkatkan aktivitas dan hasil belajar siswa. Hal ini ditujukan dengan peningkatan hasil belajar pada siklus sebesar $65 \%$ dan meningkat menjadi $85 \%$ pada siklus II. Penelitian ini juga meneliti meneliti aktivitas siswa. Aktivitas siswa pada siklus I mencapai $70 \%$ dan meningkat menjadi 90\% pada siklus II.

Penelitian kali ini juga terbukti dapat meningkatkan hasil belajar Matematika kelas 4 SDN Ujung-Ujung 03. Kelebihan penelitian ini dibandingkan penelitian yang lain adalah penggunaan model Teams Games Tournament menggunakan media pembelajaran berupa papan berat dan terbukti dapat meningkatkan hasil belajar 
Matematika pada SDN Ujung-Ujung 03. Dengan menggunakan model ini siswa akan lebih semangat dan antusias dalam mengikuti pembelajaran karena pembelajaran akan disispi games dan tournamnet, siswa dapat lebih aktif dalam pembelajaran karena siswa membangun pengetahuannya sendiri dari apa yang mereka pelajari, jadi daya serap siswa terhadap materi yang diajarkan juga lebih baik. Dari pemaparan hasil tersebut menunjukkan bahwa penelitian tindakan kelas dengan penerapan model pembelajaran Teams Games Tournament telah berhasil meningkatkan hasil belajar siswa kelas 4 SDN Ujung-Ujung 03 pada pembelajaran matematika dengan materi pengukuran berat dan panjang semester II tahun pelajaran 2018/2019.

\section{Simpulan}

Penerapan model Teams Games Tournament (TGT) beebantuan media papan beratdapat meningkatkan hasil belajar Matematika siswa kelas 4 SDN Ujung-Ujung 03 pada siklus I dan siklus II dilakukan dengan langkahlangkah sebagai berikut: 1) Penyajian kelas (class precentation) yaitu dengan penyampaian sedikit materi oleh guru dengan media papan berat, 2) Teams, siswa bekerja dalam kelompok untuk memecahkan masalah, 3) Games dimana siswa mengambil salah satu kertas dan menjawab pertanyaan dari guru secara berkelompok., 4) Tournament dimana guru mengajukan pertanyaan kepada dua kelompok yang jawabanya ada di papan berat. 5) Penghargaan dimana akan dinerikan kepada kelompok yang memiliki skor tertinggi, maka dari itu hasil belajar siswa 4 SDN Ujung-Ujung 03 meningkat.

Peningkatan hasil belajar pada pra siklus, menunjukan dari 18 siswa 12 diantaranya memiliki nilai kurang dari KKM (70) atau memiliki presentase 67\%, sedangkan siswa yang tunas terdapat 4 siswa dengan presentase $37 \%$ dengan rata rata nilai siswa 63,66. Pada siklus I terjadi peningkatan dari pra siklus. Hal ini terlihat dari peningkatan rata-rata hasil belajar siswa dari pra siklus ke siklus I menjadi 78,22. Pada siklus I siswa yang tuntas sebanyak 14 siswa dengan presentase $78 \%$ sedangkan siswa yang belum tuntas ada 4 siswa dengan presentase 22\%. Peningkatan 
terjadi pada tindakan siklus II. Peningkatan rata-rata hasil belajar siswa mencapai 85,33 dan siswa yang tuntas hasil belajar mencapai 100\% atau semua siswa tuntas.

\section{Daftar Pustaka}

Fathurrohman, M. (2015). ModelModel Pembelajaran Inovatif Alternatif Desain Pembelajaran yang Menyenangkan. Jogyakarta: AR-RUZZ MEDIA.

Mawardi. (2018). Merancang Model dan Media Pembelajaran. Scholaria: Jurnal pendidikan dan Kebudayaan, 4(3), 31.

Mulyati, S. (2016). Upaya Meningkatkan Hasil Belajar Matematika Melalui Metode Diskusi Berbantuan Media Bagan Peahan di Kelas III SD Kalisari 1. Jurnal Ilmiah Pendidikan Dasar, 3(1), 13.

Nasution, S. (2018). Meningkatkan Hasil Belajar Siswa Dengan Menggunakan Model Pembelajaran TGT Dalam Mata Pelajaran PKN Kelas VI SDN 097 Gunung Barani. Jurnal Guru Kita PGSD,1(3), 145-146.

Normala, \& Anugraheni. (2017). Peningkatan Aktivitas Belajar
Matematika Mellaui Pendekatan Poblem Based Learning Bagi Siswa Kelas 4 SD. Scholaria: Jurnal pendidikan dan Kebudayaan, 7(3), 243.

Rahayu, Wahjoedi, Sudarmiatin (2017). Peningkatan Aktivitas dan Hasil Belajar Siswa Melalui Pembelajaran Teams Games Tournament . Jurnal Pendidikan: Teori Penelitian dan Pengembangan, 2(9), 185. Saputra, Y. E., \& Slamet, S. (2016). Penerapan Model Pembelajaran Project Based Learning (PJBL) Untuk Meningkatkan Keaktifan Dan Hasil Belajar Perekayasaan Sistem Kontrol Siswa Kelas Xii Ei 3 Smk N 3 Wonosari. E-JPTE (Jurnal Elektronik Pendidikan Teknik Elektronika), 5(3), 55-60. Shoimin, Aris. 2014. 68 Model Pembelajaran Inovatif dalam Kurikulum 2013.Yogyakarta: ArRuzz Media.

Wahyudi, \& Siswanti, M. C. (2015). Pengaruh Pendekatan Saintifik melalui Model Discovery Learning dengan Permainan terhadap Hasil Belajar Matematika Siswa Kelas 5 SD. 
M.A. Romdhoni, B.S. Sulasmono, E.W. Setyaningtyas | JPDP 5 (1) April 2019, 38-49

Scholaria:Jurnal pendidikan dan Kebudayaan, 5(3), 26.

Wulansari, A. (2016). Peningkatan Hasil belajar Matematika Dengan Pembelajaran Kooperatif Teams
Games Tournament. Basic Education, 5 (25), 399.

Yustinus. (2017). Strategi Pemecahan Masalah Matematika. Salatiga: Widya Sari Press. 